\title{
Enhanced efferocytosis by dendritic cells underlies memory T-cell expansion and susceptibility to autoimmune disease in CD300f-deficient mice
}

\author{
L Tian ${ }^{1,3,4}$, S-C Choi ${ }^{1,3,4,5}$, H-N Lee ${ }^{1}$, Y Murakami ${ }^{1}$, C-F Qi ${ }^{2}$, M Sengottuvelu ${ }^{1}$, O Voss ${ }^{1}$, K Krzewski $^{1,4,6}$ and JE Coligan ${ }^{\star, 1,4,6}$
}

Homeostasis requires the immunologically silent clearance of apoptotic cells before they become pro-inflammatory necrotic cells. CD300f (CLM-1) is a phosphatidylserine receptor known to positively regulate efferocytosis by macrophages, and CD300f genedeficient mice are predisposed to develop a lupus-like disease. Here we show that, in contrast to CD300f function in macrophages, its expression inhibits efferocytosis by DC, and its deficiency leads to enhanced antigen processing and T-cell priming by these DC. The consequences are the expansion of memory T cells and increased ANA levels in aged CD300f-deficient mice, which predispose CD300f-deficient mice to develop an overt autoimmune disease when exposed to an overload of apoptotic cells, or an exacerbated autoimmunity when combined with Fc $\gamma$ RIIB deficiency. Thus, our data demonstrates that CD300f helps to maintain immune homeostasis by promoting macrophage clearance of self-antigens, while conversely inhibiting DC uptake and presentation of self-antigens.

Cell Death and Differentiation (2016) 23, 1086-1096; doi:10.1038/cdd.2015.161; published online 15 January 2016

Billions of cells die by apoptosis every day as part of the maintenance of normal homeostasis in the body. Those apoptotic cells $(A C)$ need to be rapidly and efficiently removed otherwise they will produce necrotic debris that promotes hyper-activation of the immune system, leading to autoimmune diseases like SLE. ${ }^{1,2}$ Professional phagocytes, macrophages and dendritic cells (DC), efficiently engulf $A C$ thereby preventing the release of pro-inflammatory molecules. ${ }^{3}$ Moreover, recognition and engulfment of $A C$ by macrophages and DC serves to sustain immune tolerance to self-antigens by virtue of the anti-inflammatory cytokines IL-10 and TGF- $\beta$ released from these cells, and the recruitment of natural regulatory $\mathrm{T}$ cells. ${ }^{4-7}$ Post $\mathrm{AC}$ engulfment, macrophages appear to be capable of fully digesting $A C$-associated antigens and limit their access to antigen presentation compartments, and therefore are inefficient at T-cell priming. ${ }^{8}$ In contrast, DC are highly efficient at processing and presentation of engulfed antigens, using either direct or cross-presentation pathways, which either anergizes or activates potentially self-reactive T cells, depending on the context of antigen presentation. ${ }^{9-11}$ Under homeostatic conditions, anti-inflammatory cytokines and natural regulatory $\mathrm{T}$ cells channel $\mathrm{DC}$ self-antigen presentation to induce regulatory T-cell differentiation from naïve CD4 T-cell precursors, and to tolerize effector CD8 T cells. ${ }^{12,13}$ With the impaired clearance of $A C$, subsequent necrosis leads to the release of pro-inflammatory molecules that can supply the co-stimulatory signals for self-reactive T-cell activation by DC. ${ }^{14,15}$

AC display various 'eat-me' signals on their surface that can be recognized by phagocytes. ${ }^{16,17}$ The most well-known 'eatme' signal is phosphatidylserine (PS), which is translocated from the inner leaflet to the outer leaflet of the plasma membrane during apoptosis. ${ }^{16,18,19}$ Among the many receptors known to bind $\mathrm{PS}^{20-26}$ are members of the CD300 family of receptors, including human $\mathrm{CD} 300 \mathrm{a},{ }^{27}$ mouse $\mathrm{CD}^{2} 00 \mathrm{f}^{28,29}$ and CD300b. ${ }^{30}$

The human CD300 receptors are type I transmembrane proteins with single IgV-like extracellular domains that are mainly expressed by myeloid cells. ${ }^{31-33}$ The orthologous mouse family has a variety of names, including CMRF-like molecules (CLM), ${ }^{31,32,34}$ but for simplicity in this report we use the human nomenclature for both species. Mouse CD300f (CLM-1) possesses both activating and inhibitory signaling potentials for regulation of $A C$ engulfment upon PS recognition. CD300f deficiency predisposes C57BL/6 mice to develop autoimmune disease, as the lack of CD300f accelerates

${ }^{1}$ Receptor Cell Biology Section, Laboratory of Immunogenetics, NIAID, NIH, Rockville, MD, USA and ${ }^{2}$ Pathology Core, Laboratory of Immunogenetics, NIAID, NIH, Rockville, MD, USA

*Corresponding author: JE Coligan, Receptor Cell Biology Section, Laboratory of Immunogenetics, NIAID, NIH, 12441 Parklawn Drive, Twinbrook II, Room 205, Rockville, MD 20852, USA. Tel: 1301496 8247; Fax: 1301480 2828; E-mail: jcoligan@ niaid.nih.gov

${ }^{3}$ Co-first author.

${ }^{4}$ These authors contributed equally to this work.

${ }^{5}$ Current address: Department of Pathology, Immunology, and Laboratory Medicine, University of Florida, Gainesville, FL 32610, USA.

${ }^{6}$ Co-senior author.

Abbreviations: AC, apoptotic cells; ANA, anti-nuclear antibodies; BMM, bone marrow-derived macrophage; BMDC, bone marrow-derived DC; BCR, B-cell receptor; CLM, CMRF-like molecules; CFSE, carboxyfluorescein succinimidyl ester; DC, dendritic cells; CDC, conventional DC; pDC, plasmacytoid DC; GC, germinal center; Grb2, growth factor receptor-bound protein 2; ITIM, immunoreceptor tyrosine-based inhibitory motif; ITSM, immunoreceptor tyrosine-based switch motif; MZ, marginal zone; PS, phosphatidylserine; SLE, systemic lupus erythematosus; TIM-3, T-cell immunoglobulin and mucin domain 3; TLR, toll-like receptor; WP, white pulp Received 17.6.15; revised 20.10.15; accepted 19.11.15; Edited by M Piacentini; published online 15.1.16 

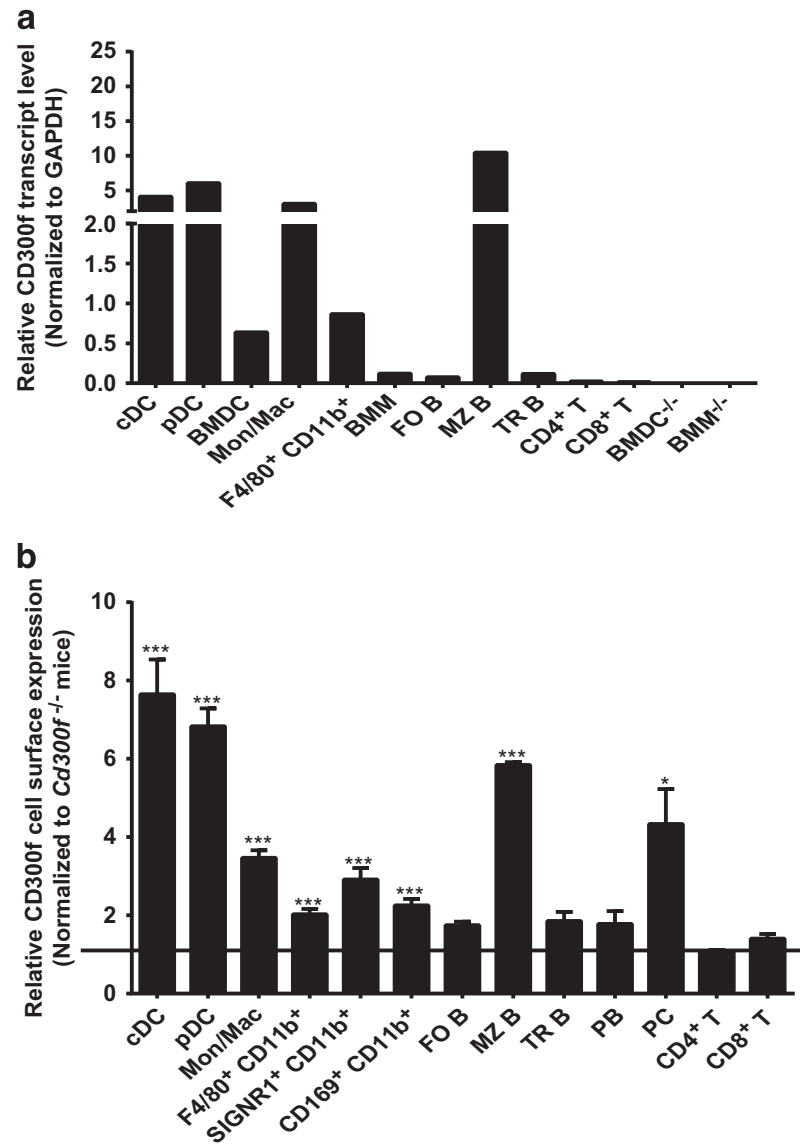

c

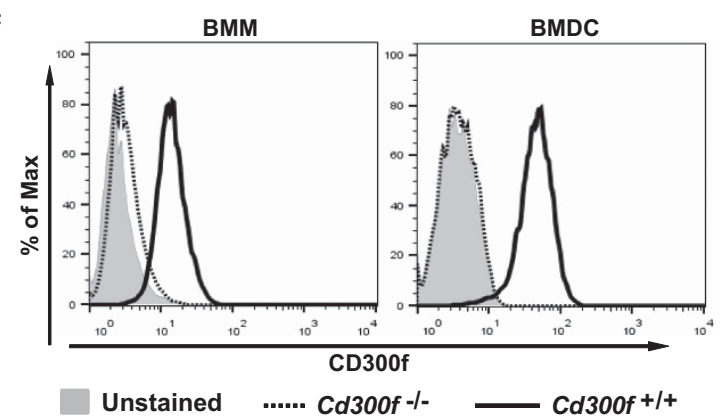

Figure 1 CD300f expression profile in immune cell populations. (a) Indicated immune cells were sorted from splenocytes or differentiated from bone marrow cells for cDNA preparation and CD300f mRNA expression levels were determined. The graph shown is representative of two independent experiments. (b) The cell surface CD300f expression was analyzed by flow cytometry on the following populations of cells: $C D C$, conventional $\mathrm{DC}\left(\mathrm{CD} 11 \mathrm{c}^{\mathrm{hi}} \mathrm{B} 22 \mathrm{O}^{-}\right), \mathrm{pDC}$, plasmacytoid $\mathrm{DC}$ $\left(C D 11 C^{10} B 220^{+} P D C A-1^{+}\right)$, Mon/Mac, monocyte or macrophages $\left(C D 11 b^{\text {hi }} C D 11\right.$ $\mathrm{C}^{-}$Ly6G $\left.^{-} \mathrm{SSC}^{\mathrm{lo}}\right), \mathrm{FO} \mathrm{B}$, follicular B cells $\left(\mathrm{B} 22 \mathrm{O}^{+} \mathrm{CD} 21^{10} \mathrm{CD} 23^{+}\right)$, MZ B, marginal zone $B$ cells $\left(B 220^{+} C D 21^{\text {hi }} C D 23^{-}\right)$, TR $B$, transitional $B$ cells $\left(B 220^{+} C D 21^{10 /}-C_{23}{ }^{-}\right.$), $\mathrm{BMDC}^{--}$, bone marrow-derived $\mathrm{DC}$ from $\mathrm{Cd} 300 \mathrm{f}^{--}$mice, $\mathrm{BMM}^{-/}$, bone marrowderived macrophages from $\mathrm{Cd}_{300 \mathrm{f}^{-}-}$mice, PB, plasmablast cells $\left(\mathrm{B} 22 \mathrm{O}^{+} \mathrm{CD} 138^{+}\right)$, $\mathrm{PC}$, plasma cells $\left(\mathrm{B} 22 \mathrm{O}^{\mathrm{lo} /}-\mathrm{CD} 138^{+}\right)$. The data is represented as the relative expression of CD300f on cells from $\mathrm{Cd}_{300 \mathrm{f}^{+/+}}$mice normalized to those from $\mathrm{Cd}_{300 \mathrm{f}^{--}}$mice. The line indicates the level of background staining on cells from $\mathrm{Cd}_{300 \mathrm{f}^{-1}}$ mice. The graph shows the mean+S.E.M. from three separate analyses. Asterisks indicate statistical significance $\left({ }^{\star} P<0.05,{ }^{* \star *} P<0.005\right)$. (c) CD300f expression on the cell surface of BMM and BMDC isolated from $\mathrm{Cd}_{300 \mathrm{f}^{+/+}}$or $\mathrm{Cd}_{300 \mathrm{f}^{--}}$mice. The graph shown is representative of two experiments
SLE-like disease development in Fcgr2b ${ }^{-/-}$C57BL/6 mice. ${ }^{29}$ However, the cellular and molecular basis underlying the regulatory function of $\mathrm{CD} 300 \mathrm{f}$ in autoimmune disease development is still unclear.

Here we found that, while CD300f functions to promote macrophage efferocytosis, its role in DC is the exact opposite, serving to inhibit $A C$ engulfment. A consequence of CD300f deficiency is a marked expansion of memory $T$ cells and increased anti-nuclear antibodies (ANA) levels in aged mice. When CD300f-deficient mice are confronted with an overload of AC, they develop an overt SLE-like disease, unlike wild-type (WT) mice. Moreover, we show that the more severe autoimmune response that develops by combining CD300f deficiency with FcyRIIB deficiency correlates with increased germinal center formation, expansion of plasma B cells, and increased serum levels of pro-inflammatory cytokines. Thus, our data show that CD300f helps to maintain homeostasis by promoting macrophage clearance of self-antigens and inhibiting DC uptake and presentation of self-antigens.

\section{Results}

CD300f expression by immune cell populations. The expression of CD300f in the immune cell populations was analyzed at both the mRNA and protein levels. DC, macrophages, marginal zone $\mathrm{B}$ cells $\left(\mathrm{B} 22 \mathrm{O}^{+} \mathrm{CD} 21^{\mathrm{hi}} \mathrm{CD} 23^{-}\right)$and plasma cells (B220 $\left.{ }^{\mathrm{lo} /}-\mathrm{CD} 138^{+}\right)$were positive for CD300f expression (Figures 1a and b). Conventional DC (cDC, CD11 $\mathrm{c}^{\mathrm{hi}}$ $\mathrm{B}_{22}{ }^{-}$) and plasmacytoid DC (pDC, CD11 $\left.\mathrm{c}^{\mathrm{l}} \mathrm{B} 22 \mathrm{O}^{+} \mathrm{PDCA}-1^{+}\right)$ showed similar levels of CD300f expression (approximately sevenfold above the background (bg) staining of cells from Cd300f ${ }^{-\alpha}$ mice). Macrophage populations ( $\mathrm{F} 4 / 80^{+}, \mathrm{CD} 169^{+}$ or SIGNR $-1^{+}$) had relatively low levels of CD300f expression (approximately threefold above bg; Figure 1b). Neither CD4 ${ }^{+}$ nor $\mathrm{CD}^{+}{ }^{+} \mathrm{T}$ cells expressed CD300f. CD300f was also expressed on both bone marrow-derived macrophages (BMM) and bone marrow-derived DC (BMDC; Figures 1a and C).

Memory T-cell expansion and increased auto-antibody production in CD300f-deficient mice. Immune cell populations were analyzed in WT and CD300f-deficient mice at different ages. As shown in Figures 2a and b, both WT and CD300f-deficient mice showed increased numbers of effector memory $\left(\mathrm{CD}_{2} \mathrm{~L}^{-} \mathrm{CD} 44^{+}\right) \mathrm{CD} 4^{+}$and $\mathrm{CD} 8^{+} \mathrm{T}$ cells, and central memory $\left(\mathrm{CD} 2 \mathrm{~L}^{+} \mathrm{CD} 44^{+}\right) \mathrm{CD}^{+} \mathrm{T}$ cells with age; these populations, however, expanded earlier and to a markedly greater extent in CD300f-deficient mice than in WT. The population of early activated $\left(\mathrm{CD} 9^{+}\right) \mathrm{CD}^{+} \mathrm{T}$ cells was maintained at the similar levels during the aging of WT mice; in contrast, a significant increase was observed in CD300fdeficient mice by 6 months that was still evident at 15 months of age (Figures $2 \mathrm{c}$ and $\mathrm{d}$ ). The population of early activated $\left(\mathrm{CD}^{+} 9^{+}\right) \mathrm{CD}^{+} \mathrm{T}$ cells tended to decrease with age in WT, but was sustained in the CD300f-deficient mice (Figure 2c), resulting in a larger population of activated $\mathrm{CD}^{+} \mathrm{T}$ cells in CD300f-deficient compared with WT mice (Figure 2d). In parallel to the hyper-activated T-cell phenotype, CD300fdeficient mice developed markedly higher levels of antinuclear auto-antibodies (ANA) by 15 months of age 
a

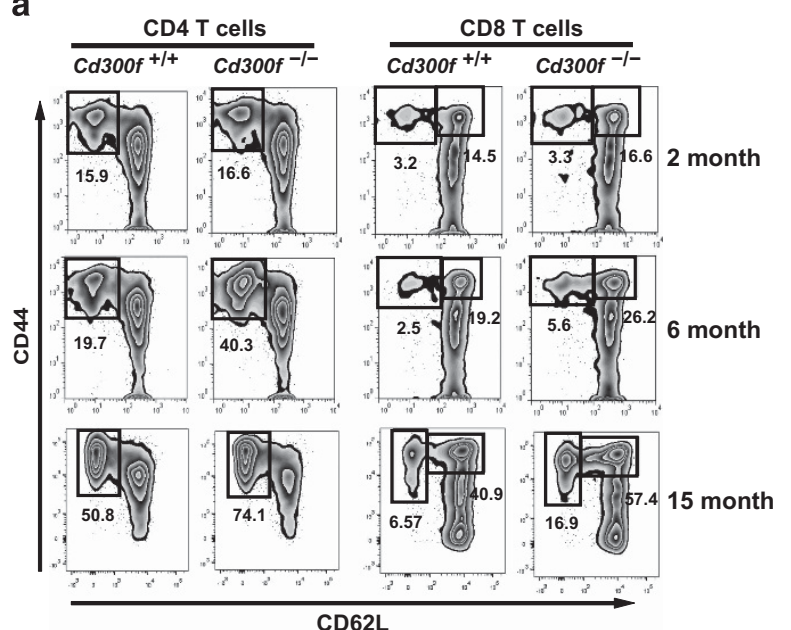

C

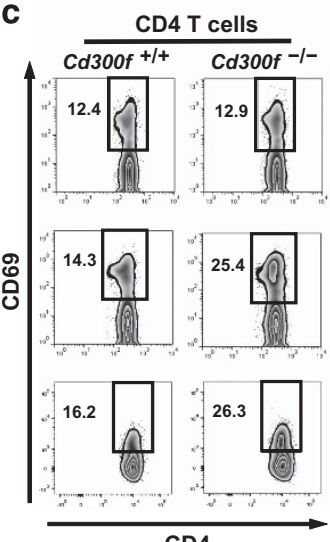

CD8 T cells
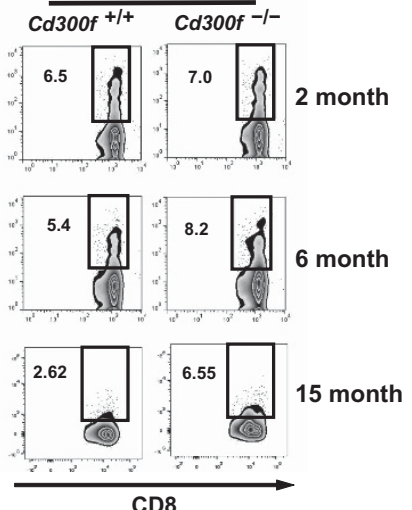

15 month
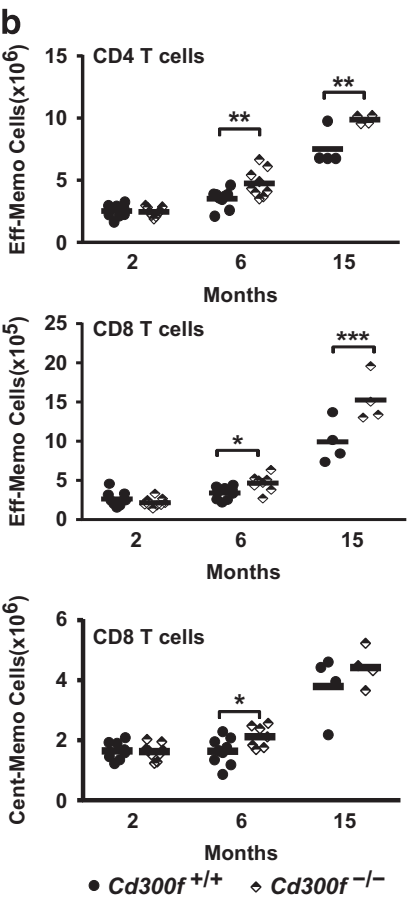

d

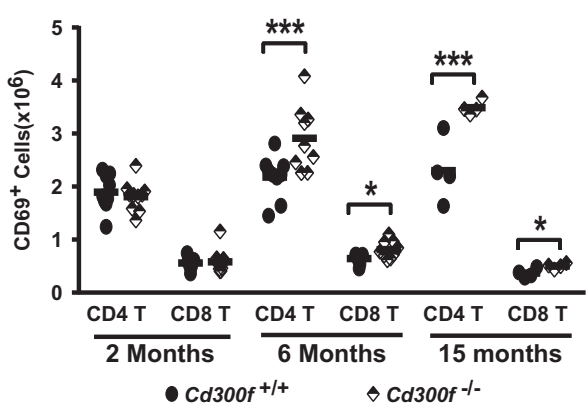

e

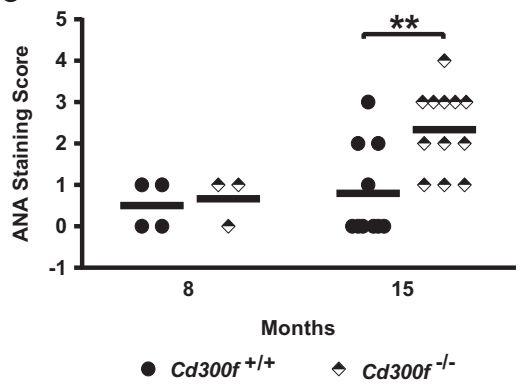

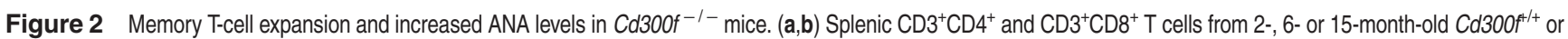
$\mathrm{Cd}_{300 \mathrm{f}^{-1}-}$ mice were analyzed for the expression of CD44 and CD62L by flow cytometry. (a) The representative contour plots illustrate the gating strategy. The numbers indicate the percentage of cells within a particular gate. (b) The graphs represent absolute numbers of effector memory $\left(\mathrm{CD} 62 \mathrm{~L}^{-} \mathrm{CD} 44^{+}\right)$or central memory $\left(\mathrm{CD} 62 \mathrm{~L}^{+} \mathrm{CD} 44^{+}\right) \mathrm{T}^{\mathrm{T}} \mathrm{cell}$ populations. Each symbol represents a mouse. Asterisks indicate statistical significance $\left({ }^{*} P<0.05,{ }^{* \star} P<0.01,{ }^{* \star *} P<0.005\right)(\mathbf{c}, \mathrm{d}) \mathrm{Splenic}_{\mathrm{CD}}{ }^{+} \mathrm{CD} 4^{+}$and $\mathrm{CD} 3^{+} \mathrm{CD} 8^{+} \mathrm{T}$ cells from 2-, 6- or 15-month-old $\mathrm{Cd} 300 \mathrm{f}^{+/+}$or $\mathrm{Cd} 300 \mathrm{f}^{-/-}$mice were analyzed for the expression of CD69 by flow cytometry. (c) The representative contour plots illustrate the gating strategy. The numbers indicate the percentage of $\mathrm{CD} 9^{+}$cells. (d) The graph shows absolute numbers of $\mathrm{CD} 9^{+} \mathrm{T}$ cells. Each symbol represents a mouse. Asterisks indicate statistical significance $\left({ }^{\star} P<0.05,{ }^{* \star *} P<0.005\right)$. (e) Fixed HEp-2 cells were used to determine the ANA levels in sera from 15-month-old $C d 300 f^{+/+}$or $C d 300 f^{-1-}$ mice. Each symbol represents a mouse. Asterisks indicate statistical significance $\left({ }^{* \star} P<0.01\right)$

(Figure 2e); however, the aged CD300f-deficient mice did not develop an overt autoimmune pathology compared to WT mice. Though a higher frequency of memory and activated $T$ cells were present in aged CD300f-deficient mice, purified $\mathrm{T}$ cells proliferated similarly to cells from WT mice upon stimulation (Supplementary Figure 1a). No other differences in cell populations and activation status were observed in aged CD300f-deficient mice compared with WT mice (Supplementary Figure 1b). Also, there were no differences in the serum cytokine or chemokine levels (TNF-a, IL-6, IFN- $\gamma$, IL-12, IL-10, MCP-1) between CD300f-deficient and WT mice (Supplementary Figure 1c). Since CD300f 
a

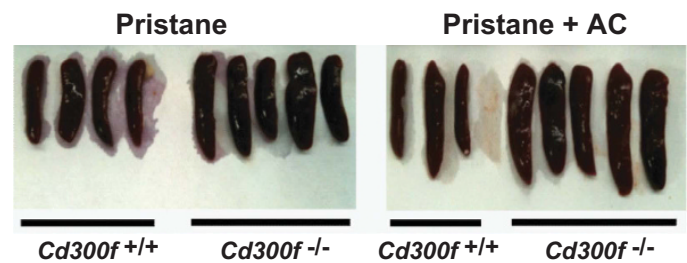

b

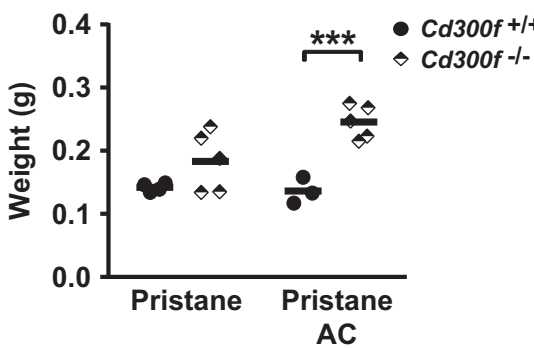

C

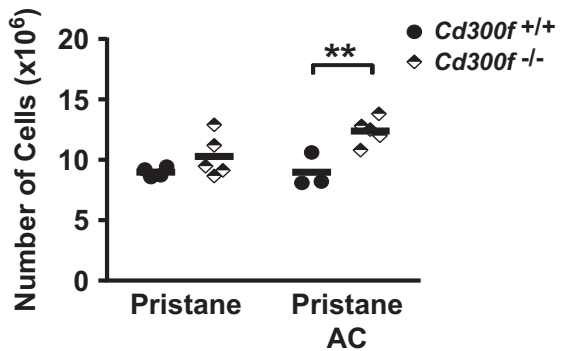

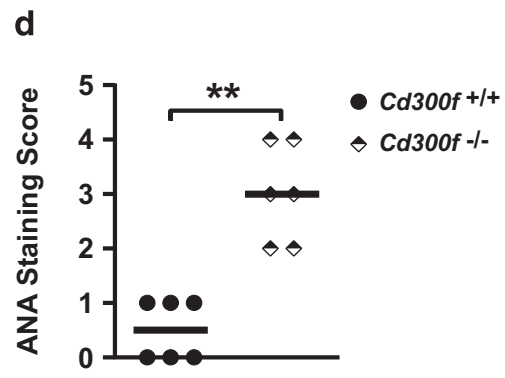
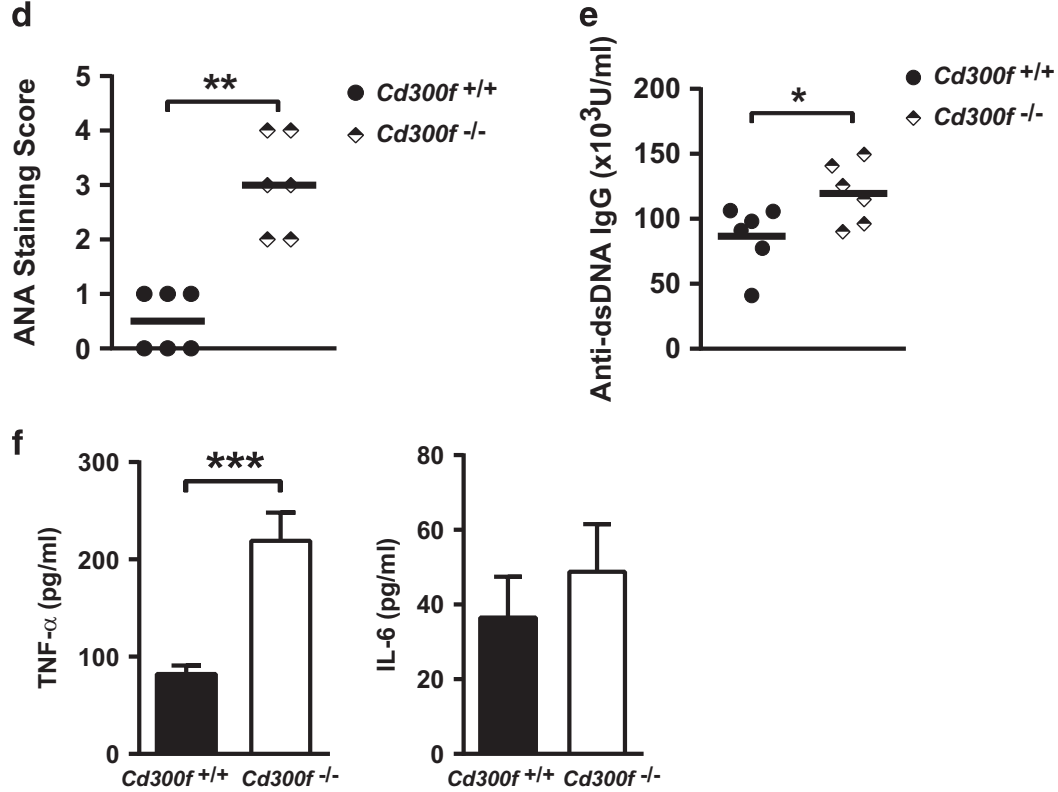

Figure 3 Exacerbated SLE-like disease development in AC-overloaded CD300f-deficient mice. (a) Photographs of spleens isolated from $\mathrm{Cd}_{300 \mathrm{f}^{\mathrm{ft}}}$ or $\mathrm{Cd} 300 \mathrm{f}^{-1-}$ mice treated with pristane alone, or pristane with AC. $(\mathbf{b}, \mathbf{c})$ Spleen weight $(\mathbf{b})$ and total number of splenocytes (c) from $C d 300 f^{f+}$ or $\mathrm{Cd} 300 \mathrm{f}^{-1-}$ mice treated with pristane alone, or pristane with AC. (d) The ANA levels in $\mathrm{Cd} 300 \mathrm{f}^{\mathrm{t}+}$ or $\mathrm{Cd}_{300 \mathrm{f}^{-1}}$ - mice treated with pristane and AC were determined by staining of fixed HEp-2 cells. (e) The serum levels of anti-

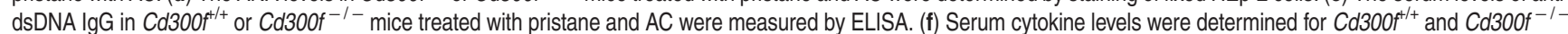
mice treated with pristane and AC using a CBA kit and flow cytometry. Data are the mean+S.E.M. of 5-6 mice per strain. Each symbol in graphs shown in b-e represents a mouse. Asterisks in $\mathbf{b}-\mathbf{f}$ indicate statistical significance $\left({ }^{\star} P<0.05,{ }^{\star \star} P<0.01,{ }^{* \star \star} P<0.005\right)$

recognition of PS mediates $\mathrm{AC}$ clearance, ${ }^{29}$ we analyzed 15-month-old mice for the presence of AC. No aberrant distribution of $A C$ was observed in the spleen, blood or peritoneum of CD300f-deficient compared with WT mice (Supplementary Figure 2).

Exacerbated SLE-like disease development in ACoverloaded CD300f-deficient mice. Although CD300fdeficient mice did not develop an overt immune phenotype, nor did they accumulate elevated levels of AC, we hypothesized that continuous exposure to $A C$ could tip the balance towards autoimmunity, as repeated exposure to AC debris has been shown to exacerbate disease in autoimmune-prone mice, but not in normal mice. ${ }^{7,35,36}$ Therefore, we injected AC into WT and CD300f-deficient mice, in the presence of pristane, an alkane that induces a SLE-like disease by promoting the release of auto-antigens from $\mathrm{AC}^{37,38}$ Although pristane alone did not cause any difference in splenomegaly between $\mathrm{Cd} 300 \mathrm{f}^{+/+}$and $\mathrm{Cd} 300 \mathrm{f}^{-/}$mice (Figures $3 a-c)$, chronic exposure to $A C$ along with pristane led to enhanced splenomegaly and ANA production in the $\mathrm{Cd}_{300 \mathrm{f}^{-1}}$ mice (Figures $3 \mathrm{a}-\mathrm{e}$ ). Serum cytokine analysis showed that TNF- $a$ was significantly increased in AC plus pristane-injected $\mathrm{Cd}_{300 f^{-/}}$mice (Figure 3f). 
a

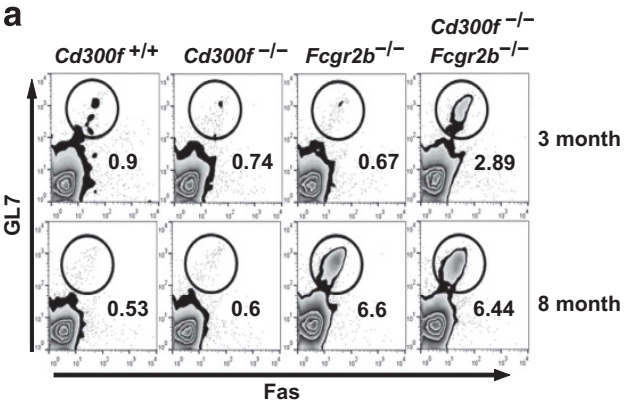

C

C
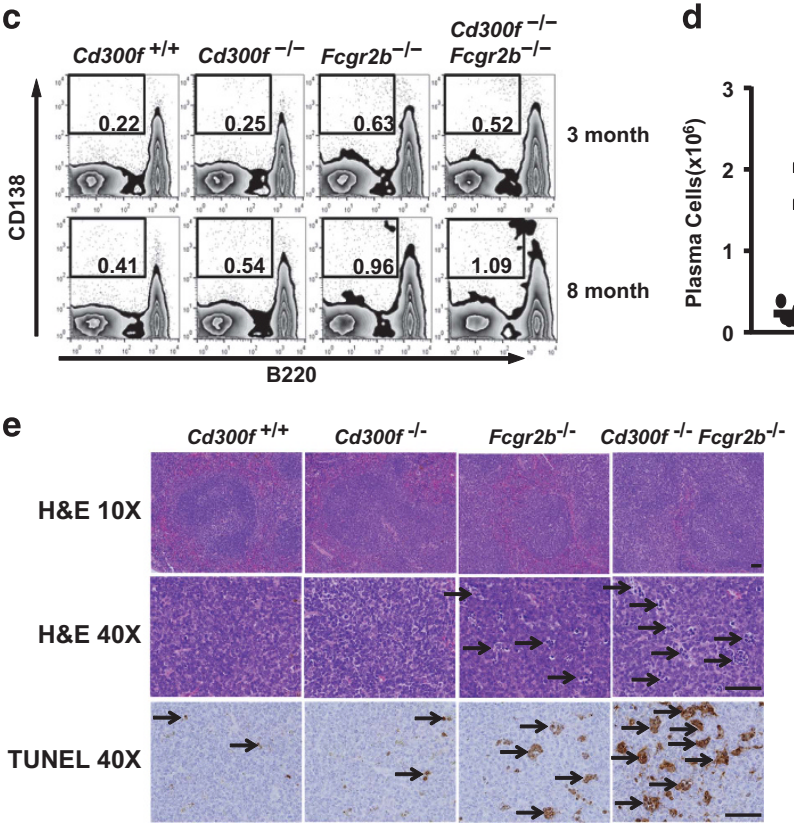

b

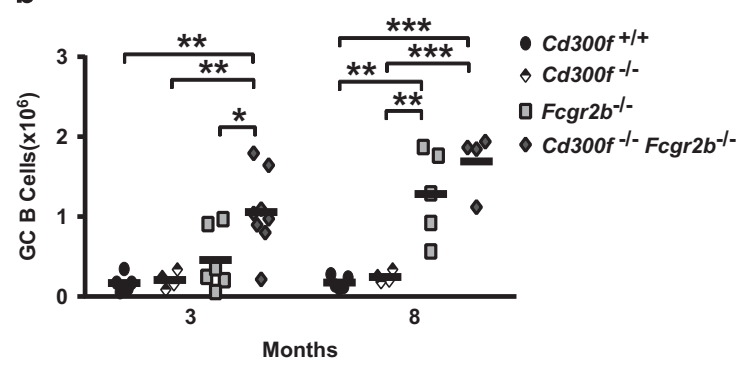

d

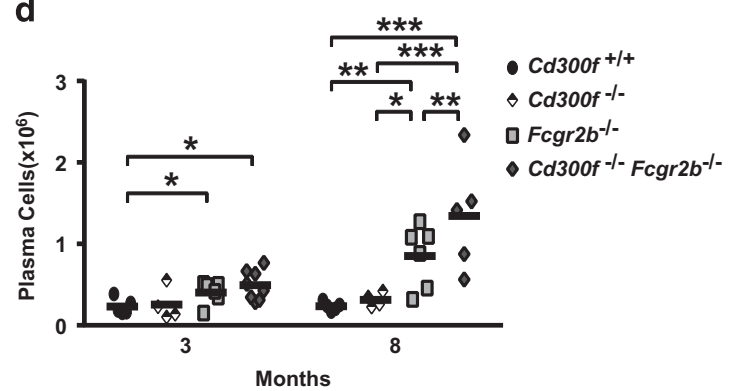

f
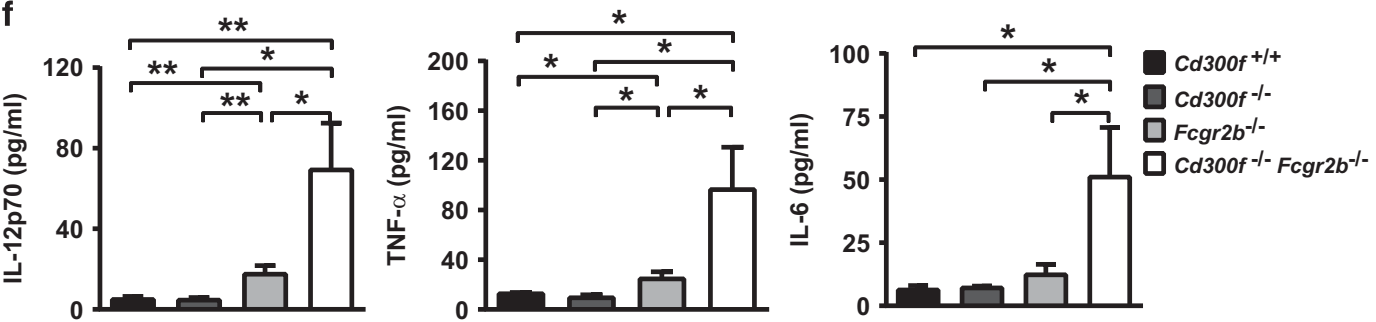

Figure 4 CD300f deficiency enhances the autoimmune response in Fcgrab $b^{-/-}$mice. (a-d) Splenic germinal center (GC) B cell (a,b, B220 $\left.\mathrm{GL}^{+} \mathrm{Cigh}^{\mathrm{Fas}}{ }^{+}\right)$and plasma cell $(\mathbf{c}, \mathbf{d}$,

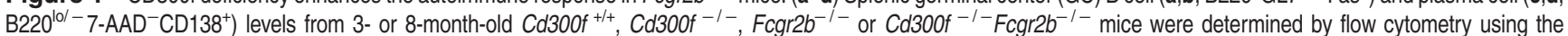
indicated markers. $(\mathbf{a}, \mathbf{c})$ The representative contour plots illustrate the gating strategy. The numbers indicate the percentage of cells within the indicated gates $(\mathbf{b}, \mathbf{d})$ The graphs summarize the absolute numbers of the indicated B-cell populations. Each symbol represents a mouse. Asterisks indicate statistical significance $\left({ }^{*} P<0.05,{ }^{* *} P<0.01\right.$,

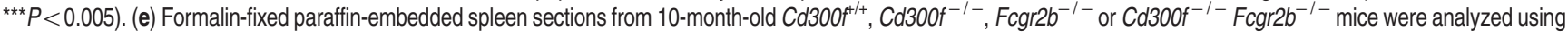
hematoxylin and eosin ( $\mathrm{H}$ and $\mathrm{E}$ ) staining and TUNEL staining. Data are representative of two mice per strain. Arrows indicate the AC. Scale bars, $50 \mu \mathrm{m}$. (f) $\mathrm{Cytokine} \mathrm{levels} \mathrm{in}$ sera of 6-month-old $\mathrm{Cd} 300 \mathrm{f}^{+/+}, \mathrm{Cd} 300 \mathrm{f}^{-1-}, \mathrm{Fcgr}_{2} \mathrm{~b}^{-1-}$ or $\mathrm{Cd} 300 \mathrm{f}^{-1-} \mathrm{Fcgr} \mathrm{b}^{-1-}$ mice were determined using a CBA kit and flow cytometry. The graphs show the mean+S.E.M. (five mice per strain). Asterisks indicate statistical significance $\left({ }^{*} P<0.05,{ }^{* *} P<0.01\right)$

CD300f deficiency causes an accelerated autoimmune response in Fcgr2b ${ }^{-/}$mice. The spontaneous development of autoimmunity in Fcgr2b $b^{-/}$C57BL/6 mice is due to the decreased activation threshold of B cells, which are easily activated by self-antigen-autoantibody immunocomplexes. ${ }^{39}$ Our previous study has shown that CD300f-deficiency predisposes mice to develop a lupus-like disease in ${\text { Fcgr } 2 b^{-1-}}$ mice. ${ }^{29}$ To further examine whether the increased levels of ANA in CD300f-deficient mice can accelerate the breakdown of B cell tolerance in Fcgr2 $b^{-/-}$mice, we analyzed germinal center $(\mathrm{GC})$ formation and plasma cell populations in 3- and 8-month-old mice. As shown in Figures 4a and b, CD300f deficiency promoted GC formation as indicated by the increased number of GC B cells in $\mathrm{Cd}_{300 \mathrm{f}^{-1}} \mathrm{Fcgr} \mathrm{b}^{-/-}$as 
compared with $\mathrm{Fcgr}_{\mathrm{Cb}} \mathrm{b}^{-/}$mice at 3 months of age. Although the total number of $B$ cells did not differ, the plasma cell population was expanded in $\mathrm{Cd} 300 \mathrm{f}^{-/} \mathrm{Fcgr}_{2 b^{-/-}}$in comparison with $F_{c g r} 2 b^{-/-}$mice at 8 months of age (Figures $4 \mathrm{c}$ and d), which was associated with a higher titer of auto-antibodies in $\mathrm{Cd}_{300 f^{-1}} \mathrm{Fcgr} \mathrm{b}^{-/-}$mice. ${ }^{29}$ An increased number of $\mathrm{AC}$ was also observed in the spleens of $\mathrm{Cd}_{300 f^{-1}} \mathrm{Fcgr} \mathrm{b}^{-1-}$ mice compared with Fcgr2 $b^{-/-}$mice (Figure $4 \mathrm{e}$ ). Moreover, a

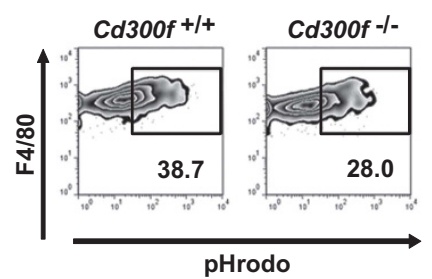

d

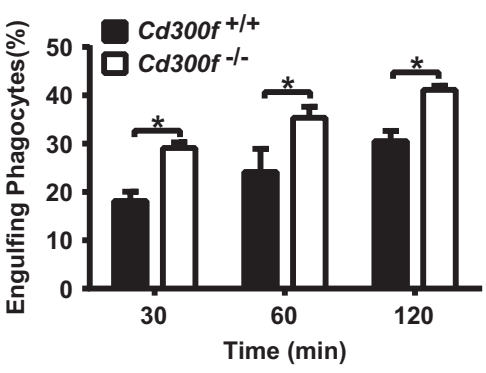

g

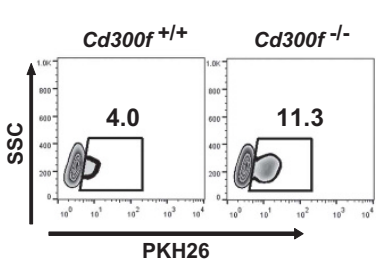

h

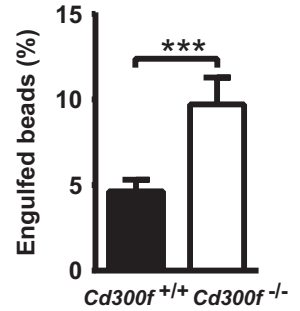

k
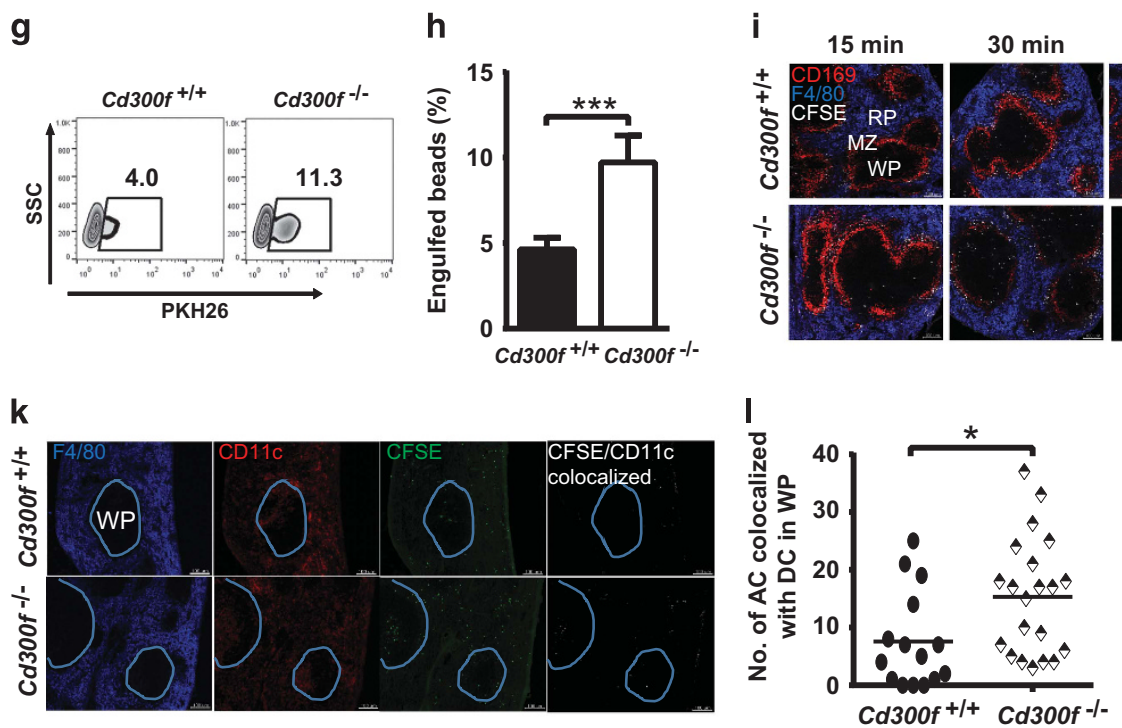

e
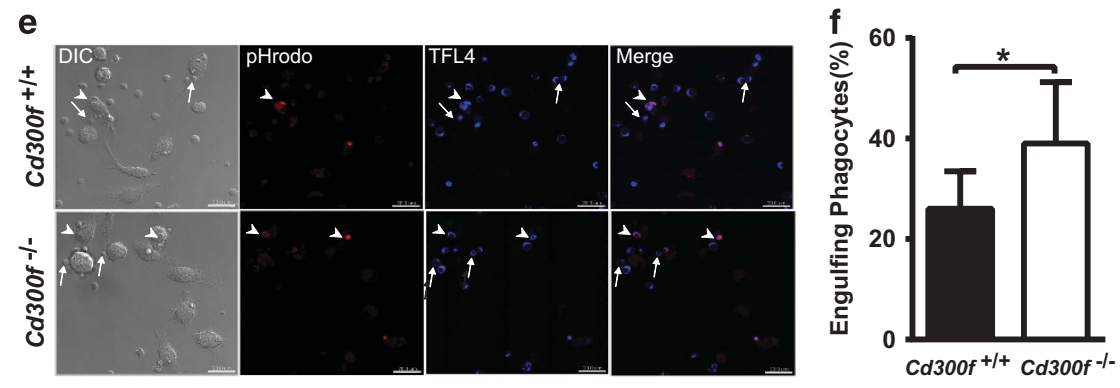

b

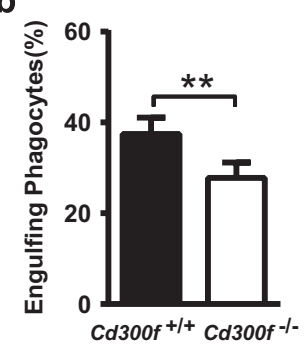

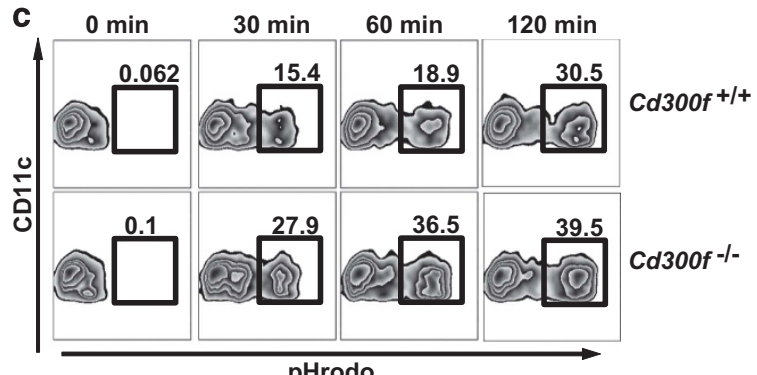

pHrodo

$\mathrm{Cd}^{200 \mathrm{f}^{+/+} \mathrm{Cd} 300 \mathrm{f}^{-1-}}$
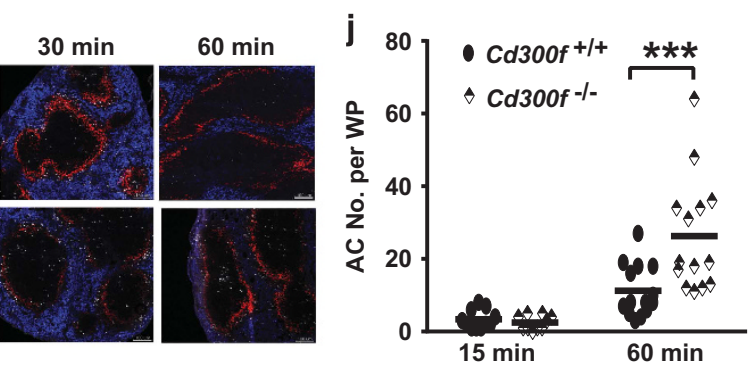

m

n

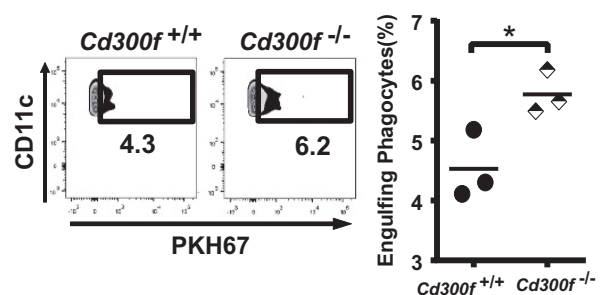

0

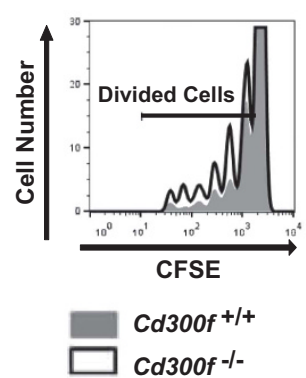

$\mathbf{q}$

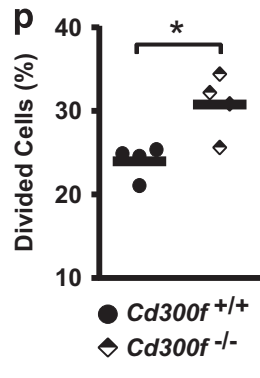

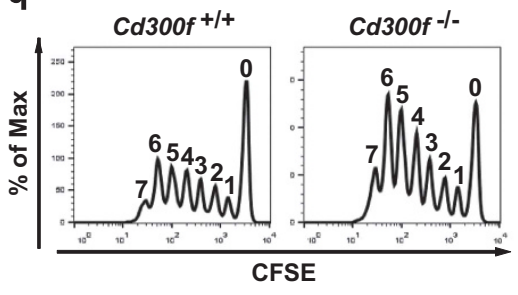

$\mathbf{r}$

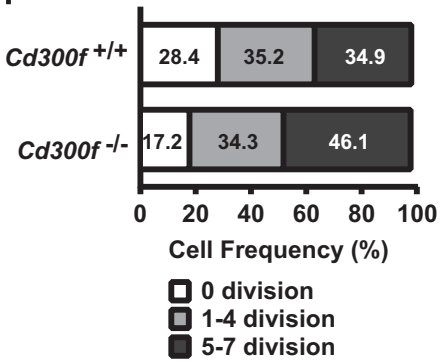

Figure 5 For caption see page 1092 
markedly elevated levels of inflammatory cytokines (IL-12, IL-6, TNF- $a$ ) were detected in the serum (Figure 4f), which was consistent with systemic inflammation observed in Cd300f $^{-/-}$Fcgr2b $^{-/-}$mice.

CD300f differentially regulates efferocytosis by macrophages and DC. CD300f expression promoted the efferocytic capacity of BMM (Figures $5 a$ and b). In contrast to the activating effect of CD300f expression on the phagocytic capacity of macrophages, its presence on DC was inhibitory, as CD300f-deficient BMDC were more phagocytic than WT BMDC (Figures 5c-f). The engulfment difference between WT and CD300f-deficient DC was unlikely due to the possibility of secondary maturational changes in the DC upon exposure to $A C$, as the added $A C$ did not change the expression of maturation markers on the DC (Supplementary Figure 3). To further exclude the possibility that AC induce a maturational change in the DC, we used PS-liposome-coated beads to mimic AC. CD300f-deficient BMDC were more efficient at engulfing PS-liposome-coated beads than WT BMDC (Figures $5 \mathrm{~g}$ and $\mathrm{h}$ ), confirming that CD300f inhibits efferocytosis by DC. To visualize the in vivo clearance of $A C$, the distribution of i.v.-injected CFSE-labeled $A C$ in spleens was analyzed. At 15 min post $A C$ injection, $A C$ were predominately distributed in marginal zone areas in both CD300f-deficient and WT mice; at 30 and $60 \mathrm{~min}$, there were more $A C$ located in the white pulp of spleens from CD300f-deficient than WT mice (Figures $5 i$ and $j$ ). The co-localization of $A C$ with $D C$ was also increased in the white pulp of spleens from CD300f-deficient compared with WT mice (Figures 5k and I). Consistently, more splenic DC from CD300f-deficient mice engulfed the i.v.-injected PKH67-labeled AC than those from WT mice (Figures $5 \mathrm{~m}$ and $n$ ). The enhanced efferocytosis by CD300f-deficient DC suggested that more AC-associated antigens would be engulfed and available to be processed and presented for T-cell priming in $C D 300 f^{-1}$ mice. To test this hypothesis, we analyzed the response of OT-I CD8 ${ }^{+} \mathrm{T}$ cells to $\gamma$-irradiated OVA-expressing EG-7 (EG-7-OVA) cells in $\mathrm{Cd} 300 \mathrm{f}^{+/+}$ and $\mathrm{Cd} 300 \mathrm{f}^{-1-}$ mice. At day 5 post injection of $\gamma$-irradiated

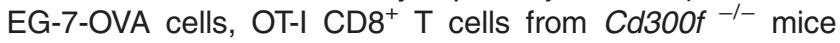
showed increased proliferation compared to those from WT mice, indicating enhanced cross-presentation in Cd300 ${ }^{-1-}$ mice (Figures 50 and $p$ ). To prove that DC were responsible for the enhanced proliferation of the OT-I CD8 ${ }^{+} \mathrm{T}$ cells from Cd300f ${ }^{-1-}$ mice, CD11 $\mathrm{C}^{+} \mathrm{DC}$ were isolated from $\gamma$-irradiated EG-7-OVA cell-immunized $\mathrm{Cd}_{300 f^{+/+}}$and $\mathrm{Cd} 300 \mathrm{f}^{-1-}$ mice after 1 day, and co-cultured with CFSE-labeled OT-I $\mathrm{CD}^{+} \mathrm{T}$ cells. The percentage of proliferating OT-I CD8 ${ }^{+}$ $\mathrm{T}$ cells showed a significant increase when exposed to CD300f-deficient DC as compared with WT DC (Figures 5q and $r$ ). Thus, CD300f deficiency renders macrophages less efficient in efferocytosis, leading to increased availability of $A C$ to be recognized by $D C$, which gain enhanced efferocytic potential and T-cell priming capability in the absence of CD300f.

Figure 5 CD300f differentially regulates efferocytosis by macrophages and DC. (a,b) $\mathrm{Cd} 300 \mathrm{f}^{4++}$ or $\mathrm{Cd} 300 \mathrm{f}^{-1-} \mathrm{BMM}$ were incubated with pHrodo-labeled apoptotic

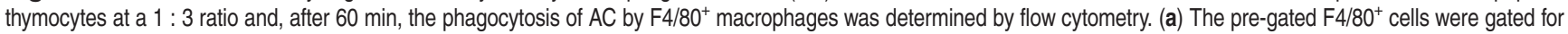
$\mathrm{F} 4 / 80^{+}$pHrodo ${ }^{+}$populations, representing the macrophages that engulfed AC. The representative contour plots show the gating strategy; the numbers indicate the percentage of $\mathrm{F} 4 / 80^{+}$pHrodo ${ }^{+}$cells. (b) The quantification summary of $\mathrm{F} 4 / 80^{+} \mathrm{pHrodo} \mathrm{C}^{+}$cells from flow cytometry analysis. The data show the mean $+\mathrm{S}$. E.M. from four independent experiments. Asterisks indicate statistical significance $\left.{ }^{* \star} P<0.01\right)$. (c,d) BMDC differentiated from bone marrow cells of $C d 300 f^{+/+}$or $C^{*} 300 f^{-1-}$ mice were used for the efferocytosis analysis as described in $\mathbf{a}$ and $\mathbf{b}$. (c) The contour plots of each time point illustrate the gating strategy for the percentage of $\mathrm{CD} 11 \mathrm{c}^{+}$pHrodo ${ }^{+}$cells from the CD11c-positive population; the numbers indicate the frequency of $\mathrm{CD} 11 \mathrm{c}^{+} \mathrm{pHrodo} \mathrm{H}^{+}$cells. (d) The quantification summary of $\mathrm{CD} 11 \mathrm{c}^{+}$pHrodo ${ }^{+}$cells from flow cytometry analysis. The data show the mean+S.E.M. from three independent experiments. Asterisks indicate statistical significance $\left({ }^{*} P<0.05\right)$. (e,f) DC differentiated from the bone marrow $(\mathrm{BMDC})$ of $\mathrm{Cd} 300 \mathrm{f}^{\mathrm{fl}+}$ or $\mathrm{Cd} 300 \mathrm{f}^{-1-}$ mice were incubated with pHrodo- and TFL4-labeled apoptotic thymocytes at a ratio of $1: 3$ for 60 mins. Next the cells were washed, immersed in the basic buffer, and imaged by confocal microscope. (e) The representative images of AC engulfment by $\mathrm{Cd} 300 \mathrm{ft}^{\mathrm{ft}}$ or $\mathrm{Cd} 300 \mathrm{f}^{-1-} \mathrm{BMDC}$. Red shows the fluorescence of pHrodo; blue shows the fluorescence of TFL4. Arrowheads indicate the engulfed AC, arrows point to tethered, non-engulfed AC; note that only the engulfed AC display strong pHrodo fluorescence. Scale bars, $20 \mu \mathrm{m}$. (f) The graph represents the means+S.E.M. of the frequency of BMDC with AC engulfment, obtained by the analysis of 50 cells from 5 or 6 random fields of view, as shown in e. Asterisk indicates statistical significance $\left({ }^{*} P<0.05\right)$. (g,h) BMDC stained with PKH26 were incubated with PS-containing-liposome-coated beads for 30 min. After homogenization and lysis of the cells, the beads either residing in or out of the phagosomes were collected for flow cytometry analysis. (g) The contour plots illustrate the gating strategy. The beads that obtained PKH26 fluorescence from the BMDC membranes during engulfment were regarded as engulfed. The numbers indicate the frequency of engulfed beads from total bead population ( $h$ ) The quantification summary of PKH26-positive beads from flow cytometry analysis. Data are the mean+S.E.M. from three independent experiments. Asterisks indicate statistical significance ${ }^{* * \star} P<0.005$ ). (i-I) CFSE-labeled AC (white in $\mathbf{i}$ and green in $\mathbf{k}$ ) were i.v. injected to $C d 300 f^{f /+}$ or $C d 300 f^{-l-}$ mice. After 15, 30 or $60 \mathrm{~min}(\mathbf{i}, \mathbf{j})$, or $60 \mathrm{~min}(\mathbf{k}, \mathbf{i})$, the spleens were collected for cryosection preparation. (i,k) Representative images are shown for cryosections stained with antiF4/80 (blue in $\mathbf{i}$ and $\mathbf{k}$ ), anti-CD169 (red in i) or anti-CD11c (red in $\mathbf{k}$ ) to visualize the red pulp (RP), marginal zone (MZ) or DC, respectively. The white pulp (WP) area was determined by the lack of anti-F4/80 and/or anti-CD169 staining; the blue outlines in (k) indicate the boundaries of WP. The rightmost panels in $\mathbf{k}$ show images of signal colocalization (white spots) between AC and DC. Scale bars, $100 \mu \mathrm{m}$. (j) The quantification summary of AC located in the splenic white pulp; data were obtained from three mice per strain in three independent experiments. Each symbol represents a white pulp positive for AC. Asterisks indicate statistical significance $\left.{ }^{* * \star} P<0.005\right)$. (I) The quantification summary of $A C$ co-localizing with $D C$ in the white pulps of spleens; the data was obtained from three mice per strain in three independent experiments. Asterisks indicate statistical significance $\left.{ }^{*} P<0.05\right)$. ( $\left.\mathrm{m}, \mathrm{n}\right)$ PKH67-labeled AC were i.v. injected to $\mathrm{Cd} 300 \mathrm{f}^{+/+}$or $\mathrm{Cd} 300 \mathrm{f}^{-1-}$ mice. After 60 mins, splenocytes were isolated, stained with Zombie$\mathrm{NIR}$, anti-CD11c and anti-B220, and analyzed by flow cytometry. $(\mathbf{m})$ The splenocytes were pre-gated on single and Zombie-NIR ${ }^{\text {low }} \mathrm{CD} 11 \mathrm{c}^{\text {hi }} \mathrm{B} 22 \mathrm{O}^{-}$cells, and then were gated on $\mathrm{CD} 11 \mathrm{c}^{+} \mathrm{PKH} 67^{+}$cells. The representative contour plots show the gating strategy; the numbers indicate the percentage of $\mathrm{CD} 11 \mathrm{c}^{+} \mathrm{PKH} 67^{+}$cells. (n) The quantification of $\mathrm{CD} 11 \mathrm{c}^{+}$ PKH67 ${ }^{+}$cells from flow cytometry analysis shown in $\mathrm{m}$. Each symbol represents a mouse, and data are representative of two experiments. The asterisk indicates statistical significance $\left({ }^{*} P<0.05\right)$. (o,p) CFSE-labeled OT-I CD8 ${ }^{+} T$ cells were adoptively transferred into $C d 300 f^{+/}$or $C d 300 f^{-1-}$ mice. After one day, the mice were then injected i.v. with $\gamma$-irradiated EG7-OVA cells. Five days later, splenic CD8 ${ }^{+} \mathrm{T}$ cells were analyzed for CFSE dilution by flow cytometry. The histograms (o) illustrate representative results of CFSE dilution seen in splenic OT-I CD8 $8^{+} \mathrm{T}$ cells from $\mathrm{Cd} 300 \mathrm{f}^{+/+}$or $\mathrm{Cd} 300 \mathrm{f}^{-1-}$ mice. The graph (p) shows the percentage of OT-I CD $8^{+} \mathrm{T}$ cell that divided. Each symbol represents a mouse, and data are representative of two experiments. The asterisk indicates statistical significance $\left.{ }^{*} P<0.05\right)$. (q,r) Proliferation of CFSE-labeled OT-I CD $8^{+} T$ cells upon incubation with $\mathrm{CD} 11 \mathrm{c}^{+} \mathrm{DCs}$ isolated from $\mathrm{Cd} 300 \mathrm{f}^{+/+}$or $\mathrm{Cd}_{300 f^{-1}}$ mice 1 day after immunization with $\gamma$-irradiated EG-7-OVA cells. The histograms (q) illustrate representative results of CFSE dilution. The graph (r) illustrates the percentage of dividing OT-I CD8 ${ }^{+} \mathrm{T}$ cells. Data are representative of two experiments 


\section{Discussion}

PS is a well-known 'eat-me' signal exposed on AC that is recognized by cell surface receptors expressed by professional (that is, macrophages and DC) and 'housekeeping' (for example, epithelial and fibroblast cells) phagocytes to mediate AC clearance for homeostasis. ${ }^{3,40,41}$ Here we show that the PS receptor CD300f is expressed on both macrophages and DC, and differentially regulates their efferocytosis. CD300f functions as an activating receptor to enhance macrophage efferocytosis, but inhibits the $A C$ engulfment by DC. Thus, CD300f possesses the potential to transduce both activating and inhibitory signals for efferocytosis. Although it is not clear at this point how CD300f differentially regulates efferocytosis in macrophages and DC, of note is the fact that CD300f has five tyrosine-based motifs in its cytoplasmic tail: two immunoreceptor tyrosine-based motifs (ITIM), an immunoreceptor tyrosine-based switch motif (ITSM), a PI3Kbinding motif and a growth factor receptor-bound protein 2 (Grb2)-binding motif. AC binding to CD300f leads to phosphorylation of the PI3K-binding motif thereby promoting PI3K recruitment and activation, which initiates the signaling events required for $A C$ engulfment; each of the other four tyrosine-based motifs initiate inhibitory signals that serve to suppress efferocytosis. ${ }^{29}$ Since all CD300f tyrosine residues have the potential to be phosphorylated in macrophages or DC upon the binding of AC (data not shown and ref. 29), whether $A C$ are engulfed or not depends on the available tyrosine kinases and/or downstream signaling capacity within the phagocytic cell. In macrophages the balance of these capabilities favors AC engulfment, while the opposite is true for DC. How CD300f expression regulates efferocytosis could also depend on the other CD300 family members expressed by the phagocyte. Overexpression of human CD300 family members has shown that CD300f tends to form homodimers, but CD300f can also form heterodimers with other CD300 family members. ${ }^{42}$ Human CD300a ${ }^{27}$ and mouse CD300b ${ }^{30}$ share PS as a ligand and are known to inhibit or potentiate efferocytosis, respectively. Whether or not CD300 heterodimer formation is unique to humans and occurs in the absence of overexpression remains to be determined. Although several immune receptors have been reported to have both activating and inhibitory cellular functions, including CD150, ${ }^{43} 2 \mathrm{~B} 4,{ }^{44}$ and PIR-B, ${ }^{45}$ we demonstrate that CD300f is the only known $\mathrm{PS}$ receptor capable of alternative signaling for efferocytosis regulation. Determining exactly how CD300f expression differentially regulates efferocytosis in different cell types is the subject of ongoing studies in our laboratory.

Our data show that CD300f-deficient macrophages are less efficient in clearing $A C$ and that the engulfment of $A C$ by $D C$ is enhanced. Efferocytosis by $D C$ is highly relevant to T-cell priming since $\mathrm{DC}$ are efficient at processing and presentation of engulfed antigens. $C D 8^{+} \mathrm{DC}$ engulf $\mathrm{AC}$ and migrate to the T-cell zone of the spleen for cross-presentation of ACassociated antigens. ${ }^{12}$ In correlation with the increased phagocytic capability of CD300f-deficient DC, more DC engulfed $A C$ in the spleen of CD300f-deficient mice, compared with WT mice. The increased availability of AC, combined with enhanced efferocytic potential of CD300f-deficient DC, likely leads to elevated presentation and cross-presentation of
AC-derived self-antigens to T cells, resulting in the observed sustained presence of activated T-cell populations and an expanded population of memory $T$ cells in aged mice. This creates more potential to trigger self-reactive $B$ cells to secrete auto-antibodies, which would explain the increased levels of ANA that we observe in aged mice.

The increase in the memory T-cell compartment and autoantibody levels did not lead to overt signs of autoimmune disease development in CD300f-deficient mice that were examined at 2-15 months of age. In elderly people, it has also been observed that there are higher levels of auto-antibodies without clinical relevance. Such individuals also have higher levels of memory and effector T cells, ${ }^{46}$ yet are in general hypo-responsive and referred to as immunosenescent. ${ }^{47-50}$ Other than the higher frequency of memory and activated $T$ cells in aged CD300f-deficient mice and the presence of elevated ANA, the T-cell proliferation in response to TCR stimulation, the activation status of macrophages or DC based on co-stimulatory molecule expression, and the levels of inflammatory or anti-inflammatory cytokines were similar between CD300f-deficient and WT mice, suggesting an immunosenescent status in aged mice. Thus, our data indicate that the autoimmune-risk status generated by CD300f deficiency occurs in the context of immunosenescence, which explains the absence of overt disease pathologies.

Although CD300f-deficient mice do not develop overt disease, they clearly are more prone than WT mice to develop overt autoimmune symptoms if stressed. CD300f-deficient mice developed a more severe autoimmune inflammation than the WT mice, when the mice were stressed with excess AC in the pristane-induced autoimmune disease model, which fits the fact that repeated exposure to AC leads to exacerbated disease in autoimmune-prone mice. .,35,36 $^{\text {Moreover, our }}$ previous study showed that CD300f-deficient $\mathrm{FCgr}_{\mathrm{Cb}} \mathrm{C}^{-/}$mice are predisposed to develop more severe splenomegaly and have a higher fatality rate than in $\mathrm{Fcgr} \mathrm{b}^{-1-}$ mice. ${ }^{29}$ Here we performed an in-depth analysis to identify cellular and molecular abnormalities behind this predisposition. In the double-deficient mice, GC B cells and plasma cells were expanded and inflammatory cytokines were increased. An enhanced accumulation of $A C$ was found in spleen tissues of double-deficient mice. These data indicate that the autoimmune-risk status due to CD300f deficiency advances to a fully activated autoimmune response once the immune activation threshold is decreased by combining CD300f deficiency with FcyRIIB deficiency, or the immune system is over-loaded with excess AC.

Interestingly, marginal zone B cells and plasma cells compared with follicular B cells or transitional B cells express a significant level of CD300f, which makes CD300f a useful marker for the identification of B-cell populations. Owing to the expression of polyreactive BCRs and higher levels of TLRs, marginal zone B cells have a lower threshold for activation, proliferation and differentiation into antibody-secreting cells than follicular B cells, and their expansion has been related to lupus-like disease development in NZB/NZW lupus-prone mice. ${ }^{51,52}$ The fact that the marginal zone $B$ cell population is not altered in CD300f-deficient mice suggests a minimal involvement of marginal zone B cells in CD300f-regulated autoimmunity development. However, we cannot exclude the 
possibility that hyper-activation of auto-reactive marginal zone $\mathrm{B}$-cell clones contributes to the increased ANA levels in 15-month-old CD300f-deficient mice as neither obvious germinal center formation nor alteration in the plasma cell population was detected. The functional effects of CD300f on marginal zone B cells and plasma cells will be further tested within the context of T-cell-dependent or -independent immune response.

Data regarding association of the CD300 family with autoimmune disease susceptibility, although exist, is limited at the moment. CD300a has been implicated in ulcerative colitis $^{53}$ and its deficiency in mice has been shown to exacerbate gut inflammation. ${ }^{54}$ A single nucleotide polymorphism (SNP) encoding a nonsynonymous substitution R94Q in the IgV-like domain of CD300a impairs its capacity to bind PS and PE, and this SNP has been linked to psoriasis susceptibility. ${ }^{55}$ The surface expression of CD300a on CD4+ $T$ cells is also lower in psoriatic patients compared with healthy controls, suggesting a role for CD300a by $\mathrm{T}$ cells in the pathogenesis of this autoimmune disease. ${ }^{55}$ Besides the SLE-like disease as shown in this study, CD300f deficiency has been shown to contribute to development and pathogenesis of experimental autoimmune encephalomyelitis and colitis in mouse models. ${ }^{56,57}$ An intronic SNP (rs10512597) of CD300f has been associated with the etiology of psoriasis disease and possibly with cardiovascular diseases. ${ }^{58,59} \mathrm{~A}$ nonsynonymous SNP (rs2034310) in the region encoding the cytoplasmic part of CD300f has been associated with multiple sclerosis. ${ }^{60}$ All those data imply that CD300 family members are likely to be important in the pathogenesis of autoimmune diseases, and highlight the potential of targeting CD300f, as well as CD300a, for the autoimmune disease therapies.

In summary, our data show that CD300f has an important role in the maintenance of immune homeostasis, by enhancing the clearance of $A C$ by macrophages and inhibiting $A C$ uptake by DC thereby limiting auto-antigen availability for T-cell priming.

\begin{abstract}
Materials and Methods
Mice. $\mathrm{Cd} 300 \mathrm{f}^{-1-} \mathrm{C} 57 \mathrm{BL} / 6$ mice were generated by OZgene and the $\mathrm{Fcgr}^{-1-}$ C57BL/6 mice were kindly provided by Dr. Silvia Bolland (National Institute of Allergic and Infectious Diseases, $\mathrm{NIH}$ ). Mice were crossed to generate the $\mathrm{Cd} 300 \mathrm{f}$ ${ }^{-l}$ - Fcgrab $b^{-1}$ mice. OT-I mice were obtained from Taconic (Hudson, NY, USA). To induce the SLE-like disease, 8-week-old female mice were injected i.p. with $0.3 \mathrm{ml}$ of pristane (2,6,10,14-tetramethyl-pentradecane, Sigma-Aldrich, St. Louis, MO, USA) at 8,12 and 16 weeks of age by i.v. injection of $10^{7}$ apoptotic thymocytes in PBS twice per week; mice injected with PBS alone were used as a control. At 3 months after the first pristane injection, mice were killed for tissue and serum collection. For the isolation of the bone marrow cells, sorting of the immune cell populations or location analysis of transferred AC in spleens, 8-10-week-old mice were used. For the immune cell population and activation status analysis, 2-, 6- or 15-month-old male mice were used. All mice were bred and housed in a pathogenfree environment in the NIAID animal facility with the protocol (LIG-5E) approved by the National Institute of Allergy and Infectious Diseases Institutional Animal Care and Use Committee.
\end{abstract}

Flow cytometry. Cells were treated with anti-CD16/32 antibody (2.4G2) to block $\mathrm{Fc}$ receptors, and then stained with the indicated Abs in PBS containing $0.2 \%$ FBS. Antibodies specific for the following molecules were used: CD3 (145-2C11), CD4 (RM4-5), CD8 (53-6.7), CD11b (M1/70), CD11c (N418), CD19 (MB19-1), CD21 (eBio8D9), CD23 (B3B4), CD40 (3/23), CD44 (IM7), CD45.2 (104), CD62L (MEL-14), CD69 (H1.2F3), CD80 (16-10A1), CD86 (GL1), CD103 (2E7), CD138 (281-2), CD169 (645608), B220 (RA3-6B2), Ly-77 (GL7), NK1.1 (PK136), PDCA-1
(eBio927), F4/80 (BM8), Fas (15A7), SIGNR1 (eBio22D1), MHC Class II I-A (AF6120.1), Ly6G (1A8) and $V \alpha 2$ TCR (B20.1). Zombie (BioLegend, San Diego, CA, USA) staining was used for the exclusion of dead cells during analysis. The monoclonal anti-CD300f was a gift from Genentech and labeled with Alexa Fluor 488 using Alexa Fluor-488 Monoclonal Antibody Labelling Kit (Invitrogen, Grand Island, NY, USA) according to the manufacturer's instruction. Annexin V (eBioscience, San Diego, CA, USA) and 7-aminoactinomycin D (7-AAD, BD Bioscience, San Jose, CA, USA) were used to detect AC. Data were collected on a FACSort or LSRII (BD Bioscience), and analyzed with FlowJo software (v.10, Tree Star, Ashland, OR, USA). In some experiments, stained cells were sorted for specific cell populations with a FACS Aria-Red (BD Bioscience).

RNA isolation and quantitative real-time PCR. RNA was isolated by RNAqueous Phenol-free total RNA isolation (Life Technologies, Grand Island, NY, USA) following the manufacturer's instructions. RNA was reverse transcribed with a qScript cDNA Synthesis Kit (Quanta Biosciences, Gaithersburg, MD, USA) according to manufacturer's instructions. For the detection of Cd300f transcript, quantitative real-time PCR was carried out with the SYBR Green PCR Master (Roche, Branchburg, NJ, USA) with the following primers $5^{\prime}$-GTGCCGATATACC TCAGGCT-3' and 5'-ATGCATCGGTTTCAACAAGA-3'. The amount of Cd300f transcript was calculated with the 2-delta CT method, where delta CT equals (CT Cd300f-CT Gapdh) and CT is the cycle at which the arbitrary detection threshold is crossed.

Measurement of serum cytokine and auto-antibody levels. Serum cytokine levels were determined using a cytometric bead array (CBA) mouse inflammation kit (BD Biosciences). Data were analyzed with CBA software (BD Bioscience). ANA in the sera of mice were detected using HEp-2 cells on microscope slides (MBL Bion, Des Plaines, IL, USA) as described previously. ${ }^{61}$ The fluorescence of ANA was detected by a Zeiss Axio Imager Upright microscope (Carl Zeiss, Thornwood, NY, USA) with a $\times 20$ Zeiss Plan-Neofluar objective. ANA staining intensity was scored in a genotype-blind fashion. The scale ranged from 0 to 4 arbitrary units, according to the following criteria: 0 , no fluorescence; 1 , very dim fluorescence; 2, dull fluorescence; 3, distinct fluorescence; and 4, high-intensity fluorescence. Serum anti-dsDNA IgG levels were quantified using a mouse antidsDNA IgG-specific ELISA kit (Alpha Diagnostic International, San Antonio, TX, USA) according to the manufacturer's recommendations. The plates were read at $450 \mathrm{~nm}$ using an ELISA plate reader.

Histology analysis. Tissue samples were fixed in 10\% buffered formalin and embedded in paraffin for sectioning and staining with hematoxylin and eosin $(\mathrm{H}$ and E). For apoptosis detection, a standard TUNEL assay was performed. Briefly, following paraffin removal and rehydration of the slides, sections were treated with Proteinase $\mathrm{K}$ and $\mathrm{H}_{2} \mathrm{O}_{2} / \mathrm{PBS}$ to block the endogenous peroxidase activity. Slides were then incubated with TdT (New England Biolabs, Ipswich, MA, USA) and the product of the reaction was detected with anti-digoxigenin-peroxidase (Roche Diagnostics, Indianapolis, IN, USA) and DAB. In some experiments, slides were counterstained with hematoxylin for microscopy observation. The histology images were evaluated by a pathologist. The amount of ACs in spleen was quantified with ImageJ.

Preparation of liposome-coated beads. Liposomes and liposomecoated M-280 Dynabeads (Invitrogen) were prepared as previously described. ${ }^{29}$ The presence of PS on the beads was confirmed by staining with Annexin V-APC (eBioscience) and flow cytometry analysis. Liposome and liposome-coated beads were stored in argon gas to prevented lipid oxidization.

Phagocytosis of AC or PS-containing-liposome-coated beads. Thymocytes from C57BL/6 mice were incubated with $10 \mu \mathrm{M}$ dexamethasone in RPMI medium with $1 \% \mathrm{BSA}$ for $6 \mathrm{~h}$ for the generation of $\mathrm{AC}^{29}$ The apoptotic thymocytes were labeled with the $\mathrm{pH}$-sensitive dye pHrodo succinimidyl ester (Invitrogen) according to the manufacturer's instruction.

BMM cells $\left(2 \times 10^{5}\right)$ were incubated with pHrodo-labeled $A C$ at a ratio of $1: 3$ for 60 min at $37^{\circ} \mathrm{C}$ and followed by anti-mouse F4/80 staining. The cells were washed and suspended in basic buffer ( $\mathrm{pH} 8.8$ ) to quench the fluorescence of non-engulfed pHrodo-labeled AC before the flow cytometry analysis. c-kit ${ }^{+}$cells isolated from bone marrow were cultured with $20 \mathrm{ng} / \mathrm{ml}$ GM-CSF and $20 \mathrm{ng} / \mathrm{ml} \mathrm{IL-4}$ for 6 days to generate the BMDC. ${ }^{62} \mathrm{BMDC}\left(2 \times 10^{5}\right)$ were incubated with pHrodo-labeled $\mathrm{AC}$ at a ratio of $1: 3$ for 30,60 and 120 min at $37^{\circ} \mathrm{C}$, and then stained with anti-mouse $C D 11 \mathrm{C}$ for the phagocytosis analysis by flow cytometry as described for BMM cells. For the 
confocal analysis of efferocytosis by $\mathrm{DC}, 5 \times 10^{4} \mathrm{BMDC}$ were incubated with pHrodoand pH-insensitive dye TFL4-labeled $A C$ at a ratio of $1: 3$ for $60 \mathrm{~min}$ at $37^{\circ} \mathrm{C}$ in $35 \mathrm{~mm}$ glass-bottomed dishes (MatTek). The cells were washed and immersed in the basic buffer to quench the fluorescence of pHrodo, but not TFL4, in the non-engulfed AC, and imaged immediately on the confocal microscope (Zeiss) with a $\times 63$ Zeiss Plan-Apochromat objective, and analyzed using LSM 710 software (v. 3.2, Carl Zeiss, Thornwood, NY, USA). The phagocytosis of liposome-coated beads has been described previously. ${ }^{30}$ Briefly, BMDC stained with PKH26 (Sigma-Aldrich) were incubated with PS-containing-liposome-coated beads for $30 \mathrm{~min}$. Cells were collected and suspended in ice-cold homogenization buffer (0.25 M sucrose, $10 \mathrm{mM}$ HEPES (pH7.4), protease inhibitor cocktail (Roche) in PBS), and then lysed by passage through a bended 27.5 gauge needle 20 times. Beads were collected from the homogenates using a Dynal magnet, washed and analyzed for PKH26 fluorescence by flow cytometry. The engulfed beads showed higher PKH26 fluorescence obtained from the cell membrane.

T-cell proliferation assay. T cells were purified from spleens of $\mathrm{Cd} 300 \mathrm{O}^{\mathrm{ft}}$ or Cd300 ${ }^{-1-}$ of 15-month-old mice with CD90.2 MicroBeads (Miltenyi Biotec, San Diego, CA, USA). Cells $\left(5 \times 10^{4}\right)$ in $100 \mu$ l complete RPMl 1640 were seeded in flat-bottom 96-well plates and stimulated with $100 \mathrm{U} / \mathrm{ml} \mathrm{IL-2} \mathrm{(National} \mathrm{Cancer}$ Institute, Frederick, MD, USA), $10 \mu \mathrm{g} / \mathrm{ml}$ anti-CD3 (BD Bioscience) and/or $2 \mu \mathrm{g} / \mathrm{ml}$ anti-CD28 (BD Bioscience). Three days later, $1 \mu \mathrm{Ci}\left[{ }^{3} \mathrm{H}\right]-\mathrm{TdR}$ was added into the wells for further culture overnight. The incorporation of $\left[{ }^{3} \mathrm{H}\right]-\mathrm{TdR}$ was measured with MicroBeta TriLux liquid scintillation counter (PerkinElmer, Waltham, MA, USA).

Confocal microscopy. CFSE-labeled apoptotic thymocytes $\left(2 \times 10^{7}\right)$ were i.v. transferred into $\mathrm{Cd}_{300 \mathrm{f}^{++}}$or $\mathrm{Cd} 300 \mathrm{f}^{-1-}$ mice at 2 months of age. Fifteen, 30 or $60 \mathrm{~min}$ later, mice were killed and spleens were collected, embedded in tissue freezing medium (TBS) and stored in $-70{ }^{\circ} \mathrm{C}$ until use. Cryosections at $5 \mu \mathrm{m}$ of thickness were fixed with acetone for $10 \mathrm{~min}$, and then blocked with $10 \% \mathrm{BSA}$ in PBS for $30 \mathrm{~min}$ at room temperature. After washing three times with PBS, the sections were incubated with APC-conjugated anti-F4/80 (Biolegend), PEconjugated anti-CD169 (Biolegend) or BV421-conjugated anti-CD11c antibodies (Biolegend) at $1: 100$ dilution for $1 \mathrm{~h}$ at room temperature. After washing, sections were mounted in ProLong Gold medium (Invitrogen) and visualized by a LSM 710 laser scanning confocal microscope with a $\times 10$ Zeiss Plan-Apochromat objective, and analyzed using LSM 710 software.

In vivo splenic DC efferocytosis. Thymocytes from C57BL/6 mice were labeled with PKH67-GL (Sigma-Aldrich) as per the manufacturer's instructions, gamma-irradiated at $20 \mathrm{~Gy}$, and incubated for $6 \mathrm{~h}$ at $37^{\circ} \mathrm{C}$ to generate ACs. Labeled AC $\left(2 \times 10^{7}\right)$ were then i.v. transferred into $\mathrm{Cd} 300 \mathrm{ft}^{1++}$ or $\mathrm{Cd} 300 \mathrm{f}^{-1-}$ mice at 2 months of age. One hour later, mice were killed and single-cell population of splenocytes was prepared. The splenocytes were stained with Zombie-NIR, PE-Cy7-conjuagted-anti-CD11c (Biolegend) and APC-conjugated anti-B220 (Biolegend) and analyzed by LSRII and FlowJo software.

Cross-priming of OT-I. CD8 ${ }^{+} \mathrm{T}$ cells were purified from OT-I transgenic mice using a CD8a ${ }^{+}$T cell isolation kit II (Miltenyi Biotec) and labeled with Vybrant CFDA SE (CFSE) Cell Tracer Kit (Invitrogen) according to the manufacturer's instructions. Cells $\left(3 \times 10^{6}\right)$ in $100 \mu \mathrm{l}$ PBS were injected i.v. into $\mathrm{Cd} 300 \mathrm{f}^{\mathrm{ft}}$ or $\mathrm{Cd} 300 \mathrm{f}^{-1-}$ mice. EG7-OVA cells were gamma-irradiated at 12000 rads. After overnight culture, $5 \times 10^{6}$ cells in $100 \mu$ l PBS were injected i.v. into mice. Five days later, splenocytes were stained with APC-conjugated anti-V $\alpha 2$ TCR (eBioscience) and analyzed for CFSE dilution by flow cytometry. For ex vivo cross-presentation assays, Cd300f ${ }^{+/+}$ or Cd300f ${ }^{-1}$ mice were injected i.v. with $\gamma$-irradiated EG-7-OVA cells $\left(5 \times 10^{6}\right.$ per mouse). One day later, DC were purified from spleen using CD11c MicroBeads (Miltenyi Biotec), followed by co-culture with CFSE-labeled OT-I CD8 ${ }^{+} \mathrm{T}$ cells at $1: 3$ ratio for 3 days. The cells were stained with APC-labeled anti-V $\alpha 2$ TCR and the CFSE dilution of the $\mathrm{CD} 8^{+} \mathrm{T}$ cells (gated on $\mathrm{V} \alpha 2 \mathrm{TCR}$ positive cells) was analyzed by flow cytometry.

Statistical analysis. Significance of the difference between groups was evaluated by two-tailed Student's $t$-test or two-way ANOVA. Alpha level was set to 0.05 .

\section{Conflict of Interest}

The authors declare no conflict of interest.
Acknowledgements. The study was supported by the Intramural Research Program of the National Institutes of Health, National Institute of Allergy and Infectious Diseases. We thank Drs. Silvia Bolland, Francisco Borrego, Alexandra Gil-Krzewska, Herbert C. Morse III, Venkateswara Simhadri and Hongsheng Wang for critically reading our manuscript. We thank Dr. Joseph Brzostowski for the technical help with the microscopy. We thank Carol Henry and Calvin Eigsti for the cell sorting. We thank Mirna Pena for handling the animal colony and Mahnaz Minai for scanning histology images.

1. Hanayama R, Tanaka M, Miyasaka K, Aozasa K, Koike M, Uchiyama Y et al. Autoimmune disease and impaired uptake of apoptotic cells in MFG-E8-deficient mice. Science 2004; 304: 1147-1150

2. Nagata S, Hanayama R, Kawane K. Autoimmunity and the clearance of dead cells. Cell 2010; 140: 619-630.

3. Flannagan RS, Jaumouille V, Grinstein S. The cell biology of phagocytosis. Annu Rev Pathol 2012; 7: 61-98.

4. Voll RE, Herrmann M, Roth EA, Stach C, Kalden JR, Girkontaite I. Immunosuppressive effects of apoptotic cells. Nature 1997; 390: 350-351.

5. Fadok VA, Bratton DL, Konowal A, Freed PW, Westcott JY, Henson PM. Macrophages that have ingested apoptotic cells in vitro inhibit proinflammatory cytokine production through autocrine/paracrine mechanisms involving TGF-beta, PGE2, and PAF. J Clin Invest 1998, 101: 890-898.

6. Ravishankar B, Shinde R, Liu H, Chaudhary K, Bradley J, Lemos HP et al. Marginal zone CD169+ macrophages coordinate apoptotic cell-driven cellular recruitment and tolerance. Proc Natl Acad Sci USA 2014; 111: 4215-4220.

7. Ravishankar B, Liu H, Shinde R, Chandler P, Baban B, Tanaka M et al. Tolerance to apoptotic cells is regulated by indoleamine 2,3-dioxygenase. Proc Natl Acad Sci USA 2012; 109: 3909-3914.

8. Delamarre L, Pack M, Chang H, Mellman I, Trombetta ES. Differential lysosomal proteolysis in antigen-presenting cells determines antigen fate. Science 2005; 307: 1630-1634.

9. Trombetta ES, Mellman I. Cell biology of antigen processing in vitro and in vivo. Annu Rev Immunol 2005; 23: 975-1028.

10. Steinman RM, Turley S, Mellman I, Inaba K. The induction of tolerance by dendritic cells that have captured apoptotic cells. J Exp Med 2000; 191: 411-416

11. Peng $Y$, Elkon KB. Autoimmunity in MFG-E8-deficient mice is associated with altered trafficking and enhanced cross-presentation of apoptotic cell antigens. J Clin Invest 2011; 121: 2221-2241.

12. Qiu $\mathrm{CH}$, Miyake $\mathrm{Y}$, Kaise $\mathrm{H}$, Kitamura $\mathrm{H}$, Ohara O, Tanaka M. Novel subset of CD8\{alpha\}+ dendritic cells localized in the marginal zone is responsible for tolerance to cell-associated antigens. J Immunol 2009; 182: 4127-4136

13. Liu K, Iyoda $T$, Saternus M, Kimura $Y$, Inaba K, Steinman RM. Immune tolerance after delivery of dying cells to dendritic cells in situ. J Exp Med 2002; 196: 1091-1097.

14. Shi Y, Evans JE, Rock KL. Molecular identification of a danger signal that alerts the immune system to dying cells. Nature 2003; 425: 516-521.

15. Urbonaviciute V, Furnrohr BG, Meister S, Munoz L, Heyder P, De Marchis F et al. Induction of inflammatory and immune responses by HMGB1-nucleosome complexes: implications for the pathogenesis of SLE. J Exp Med 2008; 205: 3007-3018.

16. Ravichandran KS. Find-me and eat-me signals in apoptotic cell clearance: progress and conundrums. J Exp Med 2010; 207: 1807-1817.

17. Ravichandran KS. Beginnings of a good apoptotic meal: the find-me and eat-me signaling pathways. Immunity 2011; 35: 445-455.

18. Chaurio RA, Janko C, Munoz LE, Frey B, Herrmann M, Gaipl US. Phospholipids: key players in apoptosis and immune regulation. Molecules 2009; 14: 4892-4914.

19. Wu Y, Tibrewal N, Birge RB. Phosphatidylserine recognition by phagocytes: a view to a kill. Trends Cell Biol 2006; 16: 189-197.

20. Kobayashi N, Karisola P, Pena-Cruz V, Dorfman DM, Jinushi M, Umetsu SE et al. TIM-1 and TIM-4 glycoproteins bind phosphatidylserine and mediate uptake of apoptotic cells. Immunity 2007; 27: 927-940.

21. Park D, Tosello-Trampont AC, Elliott MR, Lu M, Haney LB, Ma Z et al. BAl1 is an engulfment receptor for apoptotic cells upstream of the ELMO/Dock180/Rac module. Nature 2007; 450: 430-434.

22. Park SY, Jung MY, Kim HJ, Lee SJ, Kim SY, Lee BH et al. Rapid cell corpse clearance by stabilin-2, a membrane phosphatidylserine receptor. Cell Death Differ 2008; 15: 192-201.

23. Hafizi S, Dahlback B. Gas6 and protein S. Vitamin K-dependent ligands for the AxI receptor tyrosine kinase subfamily. FEBS J 2006; 273: 5231-5244.

24. Scott RS, McMahon EJ, Pop SM, Reap EA, Caricchio R, Cohen PL et al. Phagocytosis and clearance of apoptotic cells is mediated by MER. Nature 2001; 411: 207-211.

25. Akakura S, Singh S, Spataro M, Akakura R, Kim Jl, Albert ML et al. The opsonin MFG-E8 is a ligand for the alphavbeta5 integrin and triggers DOCK180-dependent Rac1 activation for the phagocytosis of apoptotic cells. Exp Cell Res 2004; 292: 403-416.

26. Hanayama R, Tanaka M, Miwa K, Shinohara A, Iwamatsu A, Nagata S. Identification of a factor that links apoptotic cells to phagocytes. Nature 2002; 417: 182-187.

27. Simhadri VR, Andersen JF, Calvo E, Choi SC, Coligan JE, Borrego F. Human CD300a binds to phosphatidylethanolamine and phosphatidylserine, and modulates the phagocytosis of dead cells. Blood 2012; 119: 2799-2809. 
28. Choi SC, Simhadri VR, Tian L, Gil-Krzewska A, Krzewski K, Borrego $F$ et al. Cutting edge: mouse CD300f (CMRF-35-like molecule-1) recognizes outer membraneexposed phosphatidylserine and can promote phagocytosis. J Immunol 2011; 187: 3483-3487.

29. Tian L, Choi SC, Murakami Y, Allen J, Morse HC 3rd, Qi CF et al. p85alpha recruitment by the CD300f phosphatidylserine receptor mediates apoptotic cell clearance required for autoimmunity suppression. Nat Commun 2014; 5: 3146.

30. Murakami Y, Tian L, Voss OH, Margulies DH, Krzewski K, Coligan JE. CD300b regulates the phagocytosis of apoptotic cells via phosphatidylserine recognition. Cell Death Differ 2014; 21: $1746-1757$.

31. Chung DH, Humphrey MB, Nakamura MC, Ginzinger DG, Seaman WE, Daws MR. CMRF-35-like molecule-1, a novel mouse myeloid receptor, can inhibit osteoclast formation. $\mathrm{J}$ Immunol 2003; 171: 6541-6548.

32. Clark GJ, Ju X, Tate $C$, Hart $D N$. The CD300 family of molecules are evolutionarily significant regulators of leukocyte functions. Trends Immunol 2009; 30: 209-217.

33. Shi L, Luo K, Xia D, Chen T, Chen G, Jiang Y et al. DlgR2, dendritic cell-derived immunoglobulin receptor 2 , is one representative of a family of IgSF inhibitory receptors and mediates negative regulation of dendritic cell-initiated antigen-specific T-cell responses. Blood 2006; 108: 2678-2686.

34. Borrego F. The CD300 molecules: an emerging family of regulators of the immune system. Blood 2013; 121: 1951-1960.

35. Mevorach D, Zhou JL, Song X, Elkon KB. Systemic exposure to irradiated apoptotic cells induces autoantibody production. J Exp Med 1998; 188: 387-392.

36. Shoshan Y, Mevorach D. Accelerated autoimmune disease in MRL/MpJ-Fas(lpr) but not in MRL/MpJ following immunization with high load of syngeneic late apoptotic cells. Autoimmunity 2004; 37: 103-109.

37. Calvani N, Caricchio R, Tucci M, Sobel ES, Silvestris F, Tartaglia P et al. Induction of apoptosis by the hydrocarbon oil pristane: implications for pristane-induced lupus. J Immunol 2005; 175: 4777-4782.

38. Lee PY, Kumagai Y, Li Y, Takeuchi O, Yoshida H, Weinstein J et al. TLR7-dependent and FcgammaR-independent production of type I interferon in experimental mouse lupus. J Exp Med 2008; 205: 2995-3006.

39. Bolland S, Ravetch JV. Spontaneous autoimmune disease in Fc(gamma)RIIB-deficient mice results from strain-specific epistasis. Immunity 2000; 13: 277-285.

40. Silva MT. Secondary necrosis: the natural outcome of the complete apoptotic program FEBS Lett 2010; 584: 4491-4499.

41. Elliott MR, Ravichandran KS. Clearance of apoptotic cells: implications in health and disease. J Cell Biol 2010; 189: 1059-1070.

42. Martinez-Barriocanal A, Comas-Casellas E, Schwartz S Jr., Martin M, Sayos J. CD300 heterocomplexes, a new and family-restricted mechanism for myeloid cell signaling regulation. J Biol Chem 2010; 285: 41781-41794.

43. Shlapatska LM, Mikhalap SV, Berdova AG, Zelensky OM, Yun TJ, Nichols KE et al. CD150 association with either the $\mathrm{SH}$-containing inositol phosphatase or the $\mathrm{SH}$-containing protein tyrosine phosphatase is regulated by the adaptor protein SH2D1A. J Immunol 2001; 166: 5480-5487.

44. Roncagalli R, Taylor JE, Zhang S, Shi X, Chen R, Cruz-Munoz ME et al. Negative regulation of natural killer cell function by EAT-2, a SAP-related adaptor. Nat Immunol 2005; 6 : 1002-1010.
45. Munitz A, McBride ML, Bernstein JS, Rothenberg ME. A dual activation and inhibition role for the paired immunoglobulin-like receptor B in eosinophils. Blood 2008; 111: 5694-5703.

46. Fagnoni FF, Vescovini R, Passeri G, Bologna G, Pedrazzoni M, Lavagetto G et al. Shortage of circulating naive $\mathrm{CD} 8(+) \mathrm{T}$ cells provides new insights on immunodeficiency in aging. Blood 2000; 95: 2860-2868.

47. Lefebvre JS, Haynes L. Aging of the CD4 T cell compartment. Open Longev Sci 2012; 6 : 83-91.

48. Prelog M. Aging of the immune system: a risk factor for autoimmunity? Autoimmun Rev 2006; 5: $136-139$.

49. Haynes L, Eaton SM, Burns EM, Randall TD, Swain SL. CD4 T cell memory derived from young naive cells functions well into old age, but memory generated from aged naive cells functions poorly. Proc Natl Acad Sci USA 2003; 100: 15053-15058.

50. Lerner A, Yamada T, Miller RA. Pgp-1hi T lymphocytes accumulate with age in mice and respond poorly to concanavalin A. Eur J Immunol 1989; 19: 977-982.

51. Martin F, Kearney JF. Marginal-zone B cells. Nat Rev Immunol 2002; 2: 323-335.

52. Wither JE, Roy V, Brennan LA. Activated B cells express increased levels of costimulatory molecules in young autoimmune NZB and (NZB x NZW)F(1) mice. Clin Immunol 2000; 94: $51-63$.

53. Burakoff R, Chao S, Perencevich M, Ying J, Friedman S, Makrauer F et al. Blood-based biomarkers can differentiate ulcerative colitis from Crohn's disease and noninflammatory diarrhea. Inflamm Bowel Dis 2011; 17: 1719-1725.

54. Tanaka T, Tahara-Hanaoka S, Nabekura T, Ikeda K, Jiang S, Tsutsumi S et al. PPAR beta/ delta activation of CD300a controls intestinal immunity. Sci Rep 2014; 4: 5412.

55. Zenarruzabeitia O, Vitalle J, Eguizabal C, Simhadri VR, Borrego F. The biology and disease relevance of CD300a, an inhibitory receptor for phosphatidylserine and phosphatidylethanolamine. J Immunol 2015; 194: 5053-5060.

56. Matsukawa T, Izawa K, Isobe M, Takahashi M, Maehara A, Yamanishi Y et al. CeramideCD300f binding suppresses experimental colitis by inhibiting ATP-mediated mast cell activation. Gut (e-pub ahead of print 11 February 2015; doi:10.1136/gutjnl-2014-308900).

57. Xi H, Katschke KJ Jr., Helmy KY, Wark PA, Kljavin N, Clark $\mathrm{H}$ et al. Negative regulation of autoimmune demyelination by the inhibitory receptor CLM-1. J Exp Med 2010; 207: 7-16.

58. Danik JS, Pare G, Chasman DI, Zee RY, Kwiatkowski DJ, Parker A et al. Novel loci, including those related to Crohn disease, psoriasis, and inflammation, identified in a genome-wide association study of fibrinogen in 17686 women: the Women's Genome Health Study. Circ Cardiovasc Genet 2009; 2: 134-141.

59. Sabater-Lleal M, Huang J, Chasman D, Naitza S, Dehghan A, Johnson AD et al. Multiethnic meta-analysis of genome-wide association studies in $>100000$ subjects identifies 23 fibrinogen-associated Loci but no strong evidence of a causal association between circulating fibrinogen and cardiovascular disease. Circulation 2013; 128: 1310-1324.

60. Ban M, McCauley JL, Zuvich R, Baker A, Bergamaschi L, Cox M et al. A non-synonymous SNP within membrane metalloendopeptidase-like 1 (MMEL1) is associated with multiple sclerosis. Genes Immun 2010; 11: 660-664.

61. Choi SC, Wang H, Tian L, Murakami Y, Shin DM, Borrego F et al. Mouse IgM Fc receptor, FCMR, promotes $B$ cell development and modulates antigen-driven immune responses. J Immunol 2013; 190: 987-996.

62. Tang X, Tian L, Esteso G, Choi SC, Barrow AD, Colonna M et al. Leukocyte-associated Iglike receptor-1-deficient mice have an altered immune cell phenotype. J Immunol 2012; 188 : 548-558.

Supplementary Information accompanies this paper on Cell Death and Differentiation website (http://www.nature.com/cdd) 